\title{
THE CONCERNS OF WORKPLACE CERTIFICATION FOR WORKING CONDITIONS AT THE GRAIN PROCESSING ENTERPRISES
}

\begin{abstract}
Abstrakt
The article analyzes one of the opportunities for the enhancement of the efficiency of grain processing productionimprovement of working conditions through the certification of the workplaces. Such action is the component of the sectorial program for development of a safety status, occupational health and the production environment, which is the task of each sectoral ministry.

The grain processing branch of the agroindustrial complex demonstrates continuous and stable growth over the past decades. It creates additional workplaces, provides employment of the population, and preserves the labor resources of the country. However, the leading branch of agroindustrial complex has no sectorial program for improvement of safety status at the workplaces. As a result, the agroindustrial complex is the third largest in work-related incidents for last years. The reasons and circumstances of incidents are stated.

The improvement of the situation is the certification of workplaces, which exercises the worker's right to healthy and safe working conditions, benefits and compensation for work in adverse working conditions. The legal and regulatory framework for certification of workplaces, the composition of the certification committee, and the procedure for certification are
\end{abstract} given.

The certification identifies the workplaces with the adverse working conditions, where it is necessary to take the first-priority measures for their improvement; the workplaces, production, jobs, professions and positions, for the employees of which it is proposed to establish benefits and compensations at the expense of the enterprise; confirms the right of employees to benefits and compensations stipulated by the legislation.

The article deals with the adaptation of the European approach to the organization of monitoring of the influence of production factors on the safety and health of the person, which serves as the basis of new methodological recommendations for the certification of workplaces for working conditions. The list of jobs with heavy, harmful and dangerous work conditions at the grain processing enterprises is offered. The mistakes and disadvantages in the course of certification are stated.

The employees of the food industry and agricultural processing sustain the occupational injuries due to labor process factors such as the severity and intensity of labor. In most cases, the causes of accidents (up to 80\%) have organizational arrangement nature, including failure to certificate the non workplaces for working conditions (or violation of the legislation on the certification of workplaces).

Key words: certification, workplaces, working conditions, production environment, hazardous and harmful production factors, labor protection, labor severity, labor intensity.

According to the Article 4 of the Law of Ukraine On Occupational Safety, one of the main principles of state policy in the area of occupational safety is "a comprehensive addressing of the occupational safety tasks on the basis of national programs on these issues and taking into account other areas of economic and social policy, achievements in the branch of science and technology and environmental protection" [1].

The Article 32 of this Law defines competence of the Cabinet of Ministers of Ukraine in the area of occupational safety, such as the development and submission of a nationwide program for the improvement of the safety status, occupational health and production environment to the Verkhovna Rada of Ukraine.

The Article 33 determines the powers of ministries and other central executive authorities in the area of occupational safety in the development and implementation of sectoral programs for the improvement of the safety status, occupational health and the production environment with the participation of trade unions. The main objective of such programs is to implement measures of sectoral importance concerning the creation of safe and harmless working conditions at the enterpris- es, institutions and organizations of the industry by implementation of specific tasks of organizational, technical, financial and administrative, scientific and legal support of activities in the area of occupational safety, and further improvement of the occupational safety management.

Over the past few years, the sectoral programs for improvement of safety status, occupational health and the production environment [2] have been successfully developed and implemented by the government agencies, such as the Ministry of Energy and Coal Industry, the Ministry of Infrastructure, the State Emergency Service of Ukraine, the Security Service of Ukraine, the Ministry of Defense of Ukraine, the State Reserve Agency of Ukraine. However, the Ministry of Agrarian Policy and Food of Ukraine, the Ministry of Internal Affairs of Ukraine, the Ministry of Youth and Sports of Ukraine, the Ministry of Regional Development, Construction and Housing and Communal Services of Ukraine, the Ministry of Culture of Ukraine, the Ministry of Health of Ukraine, the Ministry of Education and Science of Ukraine, the State Nuclear Regulatory Inspectorate of Ukraine didn't develop the sectoral programs for im- 
provement of the safety status, occupational health and production environment from 2012 to 2015.

Unfortunately, the sectoral programs on occupational safety are not currently developed for the agroindustrial complex, part of which is the grain processing industry.

In spite of the difficulties in the economy and society, the grain processing industry (elevator, milling, corn, compound feed industries) demonstrates the stable and steady growth both at large-scale enterprises, and medium and small enterprises. In 2016, 65.95 million tons of grain and grain legumes were harvested in Ukraine, in 2017 - 61,3 million tons [3]. The Ukrainian Grain Association predicts that the gross harvest of grain crops in Ukraine by 2020 can reach 100 million tons [4].

Agricultural production remains the most profitable sector of the economy, and the agricultural companies have virtually no problems in debt management and raising of new financing. The growth of profits in agriculture gave impetus to the development of warehousing (including elevator facilities). In addition, the profitability of milling and grain processing enterprises has increased recently [5].

The growth in the number and capacity of grain processing facilities means not only the creation of additional jobs to support the employment of the country's population, but also the preservation of labor resources. According to statistics, the level of work-related inci- dents, including those resulting in death, remains high in the agro-industrial complex of Ukraine (table 1) [2]. About $25 \%$ of the total number of workers of the grain processing and grain storage enterprises is involved in the particularly dangerous works [6].

Inspections of grain processing enterprises demonstrate that the occupational safety services operate, the trainings and briefings of workers are performed, and compliance with requirements of regulatory acts is controlled at most of them [7]. However, the work conditions do not meet the requirements of regulatory acts at all enterprises yet. Many of them have violations in a safe arrangement of work in the workplace: violation at the stations of loading and unloading of railway cars; safety of silos cleaning is not supported; technological equipment is operated with violations of safety requirements; there are cases of violations in the management of documentation for electrical plants, truck unloaders and some types of hazardous works.

An effective and necessary measure in the comprehensive assessment of all factors of the production environment and labor process, concomitant socioeconomic factors that have influence on the health and performance of workers in the course of employment is the certification of workplaces.

The workplace certification for working conditions has been introduced in Ukraine by the Resolution of the Cabinet of Ministers dated August 1, 1992 No. 442 to

Table 1. Status of the work-related incidents for 12 months of 2017 and 2016 by sectors of supervision (persons) [2]

\begin{tabular}{|c|c|c|c|c|c|c|}
\hline \multirow[t]{2}{*}{ Sector of supervision } & \multicolumn{2}{|c|}{12 months of 2017} & \multicolumn{2}{|c|}{12 months of 2016} & \multicolumn{2}{|c|}{ Difference, $+/-$} \\
\hline & Total & $\begin{array}{l}\text { including } \\
\text { fatal cases }\end{array}$ & Total & $\begin{array}{l}\text { including } \\
\text { fatal cases }\end{array}$ & Total & $\begin{array}{l}\text { including } \\
\text { fatal cases }\end{array}$ \\
\hline Coal & 780 & 23 & 864 & 20 & -84 & 3 \\
\hline Mining and non-metal mining & 201 & 9 & 192 & 23 & 9 & -14 \\
\hline $\begin{array}{l}\text { Oil-and-gas extraction industry and oil } \\
\text { and gas exploration }\end{array}$ & 20 & 3 & 23 & $\overline{5}$ & -3 & -2 \\
\hline Power industry & 121 & 16 & 136 & 15 & -15 & 1 \\
\hline Construction & 224 & 54 & 184 & 41 & 40 & 13 \\
\hline Boiler inspection, lifting devices & 16 & 9 & 20 & 6 & -4 & 3 \\
\hline Engineering industry & 336 & 19 & 313 & 19 & 23 & 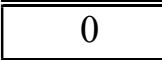 \\
\hline Metallurgical industry & 260 & 13 & 255 & 12 & $\overline{5}$ & 1 \\
\hline Chemical industry & 128 & 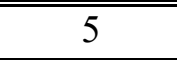 & 146 & 10 & -18 & -5 \\
\hline Transport & 393 & 65 & 364 & $\overline{770}$ & 29 & $-\overline{-5}$ \\
\hline Communications & 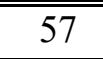 & 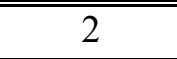 & 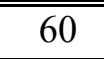 & 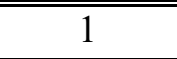 & 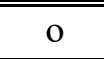 & 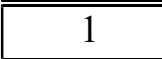 \\
\hline Gas industry & 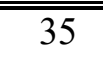 & 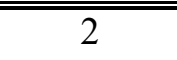 & 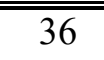 & 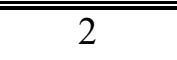 & -1 & 0 \\
\hline Housing and utilities & 155 & 17 & 167 & 33 & -12 & $\overline{-16}$ \\
\hline Agroindustrial complex & 537 & 75 & 578 & 83 & -41 & -8 \\
\hline Wood processing industry & 76 & 7 & 51 & 2 & 25 & 5 \\
\hline Light and textile industry & 23 & 1 & 22 & 0 & 1 & 1 \\
\hline Social and cultural sphere and trade & 951 & 46 & 1017 & 58 & -66 & -12 \\
\hline T O $\quad \mathrm{T} A \mathrm{~L}$ & 4313 & 366 & 4428 & 400 & -115 & -34 \\
\hline
\end{tabular}


regulate the relationship between the owner and the workers in terms of exercise of the rights to healthy and to regulate the relationship between the owner and the workers in terms of exercise of the rights to healthy and to regulate the relationship between the owner and the workers in terms of exercise of the rights to healthy and safe working conditions, benefits and compensation for work in adverse working conditions [8]. The manager of the enterprise, institution, organization shall bear the responsibility for timely and quality certification.

The results of the workplace certification are the basis not only for provision of the benefits and compensations to workers for work in adverse working conditions stipulated by the current legislation, but also for the development and implementation of measures aimed at improvement of the working conditions of employees through the introduction of advanced technologies.

The legal platform for the certification of workplaces for working conditions is laid down in the Constitution of Ukraine, the laws of Ukraine, and the resolutions of the Cabinet of Ministers of Ukraine.

The workplace certification for working conditions is organized and held by this time in accordance with the abovementioned "Procedure for certification of workplaces for working conditions" (1992); "Procedure for social and hygienic monitoring" approved by the resolution of the Cabinet of Ministers of Ukraine dated 22.02.2006, No. 182; "Methodological recommendations for the workplace certification for working conditions" approved by the Resolution of the Ministry of Labor and Ministry of Health dated 01.09.1992 No. 41, by the Resolution of the Cabinet of Ministers of Ukraine dated 05.10.2016 No. 741 "On Amendments to some Resolutions of the Cabinet of Ministers of Ukraine and invalidation of certain acts of the Cabinet of Ministers of Ukraine and the Council of Ministers of the Ukrainian SSR".

The analysis of these documents by the specialists of the State Enterprise "National Research Institute of Industrial and Occupational Safety" indicates the need for their improvement, taking into account the new "Health-based Classification of Labor in terms of Hazard and Danger of the Industrial Environment and Labor Process Factors" approved by the decree of the Ministry of Health of Ukraine dated 08.04.2014 No. 248, amendments to the legislative acts, achievements in the area of hygiene and occupational safety, as well as the identification of the shortcomings when using the existing "Procedure of for certification of workplaces for working conditions" in the course of workplace certification during the period from 1992 up to this day [9].

By the way, new Labor Protection Regulations for workers engaged in grain storage and processing approved by the order of the Ministry of Social Policy of Ukraine dated 20.09.2017 No. 1504 took effect, which abolished the Occupational Safety and Sanitation Regulations for grain storage and processing enterprises of the Ministry of Bread Products of the USSR approved by the order of the Ministry of Bread Products of the USSR dated 18.04.1988 No. 99, which had been valid for many years [10].

According to the requirements of the new Regulations, the employer shall review and approve the local acts of enterprises, labor protection instructions, develop new cards (passport) of technological processes and certify workplaces for working conditions at the workplaces where the technological process, used equipment, raw and other materials are potential sources of harmful and hazardous production factors, adherence to admissible standards of dangerous and harmful production factors at the industrial premises and workplaces, etc.

According to the procedure of certification of workplaces, the administration of an enterprise shall study the occupational health and safety standards in relation to its production, as well as analyze the following:

- list No. 1 of production, works, professions, positions and indicators for underground works, works with extremely harmful and extremely difficult conditions of employment, with full-time employment entitling to retirement pension on a preferential basis, approved by the resolution of the Cabinet of Ministers dated 24.06.2016 No. 461;

- list No. 2 of production, works, professions, positions and indicators for works with harmful and difficult conditions of employment, with full-time employment entitling to retirement pension on a preferential basis, approved by the resolution of the Cabinet of Ministers No. 461;

- lists of productions, works, workshops, professions and positions, with employment entitling to annual additional leaves for work under harmful and difficult working conditions and special nature of work, approved by the resolution of the Cabinet of Ministers of Ukraine dated 17.11.1997 No. 1290;

- list of production, workshops, professions and positions with harmful working conditions, with employment entitling to reduced working week, approved by the resolution of the Cabinet of Ministers of Ukraine dated 21.02.2001 No. 163.

If the employer finds in these documents the works, factors, professions existing at the workplace of a particular enterprise, it shall certify such places. Moreover, the certification shall be conducted regardless of whether the employer is a legal entity or a private entrepreneur.

According to the decree "On Procedure for certification of workplaces for working conditions", for the organization and holding of certification, the manager of the enterprise shall issue an order, which specifies the grounds and tasks of certification, determines the composition of the certification committee, establishes the terms and schedule for both preparatory works and certification itself, specifies the project and research organizations that are necessary for the scientific and technical assessment of working conditions and development of measures for their optimization $[11,12]$.

The certification is conducted directly by the certification committee, which should involve key specialists, employees of the personnel department, labor and salaries, labor protection, representatives of NGOs, etc. The general procedure for certification is as follows:

- the necessary legal and informational reference base is formed and its study is arranged;

- plans are prepared for the placement of equipment for each unit and the boundaries of the placement of 
workplaces are determined, a list of workplaces to be certified is prepared;

- the factors of the production environment and labor process are studied;

- the conformity of the professions and positions of the employees working at the studied workplaces with the nature of the actual works shall be established based on the Unified Tariff Qualification Guide;

- Chart of working conditions is drawn up for each workplace or group of similar places; performed;

- hygienic assessment of working conditions is

- assessment of the technical and organizational level of the workplace is performed;

- the workplace is assessed in its entirety, taking into account the influence of all factors of the production environment and labor process stipulated by the healthbased classification of labor on the employees, as well as the influence of the technical and organizational level of working conditions and the degree of risk of damage to health;

- the workplaces are reduced or streamlined;

- the existing proposals are clarified and new proposals are introduced for the establishment of benefits and compensations, depending on the working conditions, the material costs for these goals are determined [8].

The results of the study are recorded in the "Chart of working conditions". According to the results of the certification, the following list is prepared:

- list of workplaces, production, works, professions and positions, where the employees have confirmed right to benefits and compensation provided for by law;

- list of workplaces, production, works, professions and positions, where the employees are offered to establish benefits and compensations at the expense of the enterprise in accordance with Art. 26 of the Law of Ukraine On Enterprises and Art. 13 of the Law of Ukraine On Pension Provision;

- list of workplaces with unfavorable working conditions, where it is necessary to take immediate measures to improve them.

The certification materials are approved by the order of the enterprise, organization and kept for 50 years.

Under the conditions of today, the study and creative adaptation of European approaches to the organization of own system for monitoring of the impact of production factors on the safety and health of humans, starting from each production facility (institution), is very relevant. The monitoring procedure includes qualitative and quantitative measurements and assessment of the safety status and working conditions that are currently presented at the enterprises in the form of workplace certification. But taking into account the best practices of foreign countries, the certification should not focus on benefits and compensations, but on the preventive direction: the development of measures to improve working conditions and improve the health of the workers.

Together with the specialists of the scientific institutions of the Ministry of Health of Ukraine, the State Enterprise "National Research Institute of Industrial and Occupational Safety" has developed new "Methodologi- cal recommendations for workplace certification for working conditions", which should strengthen the requirement for employers to adhere to the established procedure for certification of the workplaces, strengthen the role of the officials, who are responsible for occupational safety and encourage an increase in the number of workplaces that meet the regulatory occupational safety requirements [13].

Today, there is a problem with the subject of certification - the workplaces that fall under the certification. According to State Sanitary Rules and Regulations "Health-based Classification of Labor in terms of Hazard and Danger of the Industrial Environment and Severity and Intensity of Labor Process" (2014), the list of works with heavy, harmful and dangerous working conditions at grain processing enterprises may include the following:

- disinfectation and deratization works to combat granary insects with the use of poisonous substances, as well as packaging and unloading of toxic chemicals;

- loading and unloading of grain and packaging goods and control of handling mechanisms when loading and unloading at the premises, cars and holds of vessels;

- sieving of flour wastes with manual sack filling, sieving of products of grinding of grain and other semi-finished products on siftings and other sieving machines during mill operation with mechanical transport;

- corn seed treatment in the course of work toxic chemicals;

- process of hydrothermal treatment of grain, cereals, other products and semi-finished products in steamers, steam dryers, cooking units and other devices of various designs;

- transportation of flour, semi-finished products, finished products in a non-mechanized way;

- beating and cleaning of the previously used soft packages;

- process of preparation of enrichment mixtures for impurities in different types of flour and types of mixed feed;

- maintenance of ventilation and aspiration units, cleaning of aspiration pipes and units, etc. [9].

But after the adoption of the abovementioned resolution of the Cabinet of Ministers of Ukraine No. 461 "On the approval of the lists of productions, works, professions and positions, with employment entitling to retirement pension on a preferential basis", a number of professions was deleted from the list No. 1 and No. 2, which prior to adoption of this document were the professions related to harmful working conditions, and the latter, in turn, are confirmed by the implemented workplace certifications. The issue of extraordinary certification is also unclear, namely who identifies a fundamental change in the conditions and nature of work.

The certification of laboratories in accordance with the Project of new "Methodological recommendations for workplace certification for working conditions" should be carried out under the same requirements for all laboratories, with the identification of departments that will certify.

In practice, the employers often neglect many important aspects of workplace certification. In particular, if the employer does not include involve the experts 
with specific knowledge in the certification committee, the significant errors may occur during the certification process. In addition, there is a reduction of research into the number of harmful production factors at the workplace, since the list of these factors is determined by the employer itself for the laboratory control in the course of certification. The reason for this is that some employers are not interested in a full objective assessment of working conditions, and sometimes they try to reduce the cost of research in order to save money. The disadvantages of the certification may involve the cases of reducing the indicators of harmfulness of production factors to the limit of permissible standards.

The study implemented by the researchers of the State Enterprise "National Research Institute of Industrial and Occupational Safety" and specialists of the relevant state labor protection supervision bodies in relation to the status of work-related incidents caused by factors of the production environment and labor process found that the workers of the food industry and processing of agricultural products represent one third of the persons who suffered work-related incident due to the factors of the labor process. The last group of factors includes the severity and intensity of labor.

In most cases, the reasons for incidents (up to $80 \%$ ) are causes of organizational nature. Failure to certify the workplaces for working conditions (or violation of the legislation on workplace certification) is one of such reasons. It is the employer who is directly responsible for the timely and high-quality implementation of the workplace certification and may be brought to administrative and criminal liability in case of violations.

An example for the study of the best practices in the area of industrial safety is LLC "JV "NIBULON", one of the leaders of the domestic agrarian market [14]. The company regularly conducts certification of workplaces for working conditions and takes a set of measures aimed at prevention of the injuries and occupational diseases of organizational, technical, sanitary-hygienic, socio-economic, legal and medical-preventive nature. Each year, the "Comprehensive measures to achieve the established standards of safety, occupational health and production environment, improvement of the existing level of occupational safety, prevention of occupational injuries, occupational diseases, accidents and fires" are developed and improved.

Consequently, every employer must understand that today, against the background of the complication of technical systems and processes, the problem of obtaining information on the factors of the production environment at individual workplaces in the food industry in general and at grain processing enterprises in particular can be solved through the existing system of certification of workplaces. And improvement of this system will make it possible to prevent the work-related incidents and occupational diseases and thereby increase the competitiveness of the enterprise.

\section{REFERENSES}

1. [Electronic resource]/Available at: http://zakon2.rada.gov.ua/laws/show/178-18.

2. [Electronic resource]/Available at: http://dsp.gov.ua/

3. [Electronic resource]/Available at: https://economics.uman.ua/agro/2375453-ukrajina-za-rik-zibrala-bilshe-61milyona-tonn-zerna.html

4. [Electronic resource]/Available at: http://agravery.com/uk/posts/show/valovij-zbir-zernovih-v-ukraini-do-2020roku-moze-dosagti-100-mln-tonn

5. [Electronic resource]/Available at: http://agravery.com/uk/posts/show/silskogospodarski-kompanh-demonstruutnajmensu-castku-problemnih-borgiv-nbu

6. [Electronic resource]/Available at: http://nemyriv-rda.gov.ua/index.php/377-dotrymannia-vymoh-bezpeky-napidpryiemstvakh-zernozberihannia-i-pererobky-zerna

7. [Electronic resource]/Available at: http://www.dnop.gov.ua/index.php/uk/pres-sluzhba/vsi-novini/2254-1646

8. On Procedure for certification of workplaces for working conditions [Electronic resource]/Available at: http://zakon.rada.gov.ua/laws/show/442-92-n.

9. State Sanitary Rules and Regulations "Health-based Classification of Labor in terms of Hazard and Danger of the Industrial Environment and Severity and Intensity of Labor Process// Official Bulletin of Ukraine - 2014. - No. 41. p. 95-132.

10. On approval of Labor Protection Regulations for workers engaged in grain storage and processing [Electronic resource] / Available at: http://zakon.rada.gov.ua/laws/show/zl288-17.

11. 11 On approval of the lists of productions, works, professions and positions, with employment entitling to retirement pension on a preferential basis [Electronic resource] / Available at: http://zakon.rada.gov.ua/laws/show/461-2016$\% D 0 \% B F$.

12. On approval of the lists of productions, works, professions and positions with harmful working conditions, with employment entitling to reduced working week [Electronic resource]/ Available at: http://zakon.rada.gov.ua/laws/show/163-2001-\%D0\%BF14.

13. $V$. Engstrem. Development of the project of methodological recommendations for the certification of workplaces for working conditions / Engstrem V.B.//Labor protection newsletter. - No. 1 (83) 2017. - p.32-43.

14. [Electronic resource]/Available at: http://www.nibulon.com/data/investiciina-diyalnist/dlya-investoriv/promislovabezpeka-i-oxorona-zdorovya.html 
О.О.ФЕСЕНКО, канд. техн. наук, доцент,

В.М. ЛИСЮК, канд. техн. наук, доцент, 3.М. САХАРОВА, ст. викладач Одеська національна академія харчових технологій, м. Одеса

\section{ПРОБЛЕМНІ ПИТАННЯ АТЕСТАЦІї РОБОЧИХ МІСЦЬ ЗА УМОВАМИ ПРАЦІ НА ЗЕРНОПЕРЕРОБНИХ ПІДПРИЕМСТВАХ}

\section{Анотація}

У статті надається аналіз однієї із можливостей підвищення ефективності зернопереробного виробництва - поліпшення умов праці шляхом проведення атестаиії робочих місць. Такий захід є складовою галузевої програми поліпшення стану безпеки, гігієни пращฺі та виробничого середовища, щзо є завданням кожного галузевого міністерства.

Зернопереробна галузь агропромислового комплексу показує постійне та стабільне зростання протягом останніх десятиліть. Це створює додаткові робочі місия, забезпечує трудову зайнятість населення, зберігає трудові ресурси краӥни. Але у провідній галузі агропромислового комплексу відсутня галузева програма поліпшення стану безпеки на робочих місиях. Через ие агропромисловий комплекс займає третє місие за рівнем виробничого травматизм за останні роки. Наведені причини та обставини нещуасних випадків.

Покращанням ситуащії є атестація робочих місць, щуо реалізує право робітника на здорові й безпечні умови праці, пільги та компенсащіï за роботу у несприятливих умовах праці. Наведена нормативно-правова база для проведення атес-

тації робочих місиьь, склад атестаційної комісії, порядок проведення атестаиії.

Атестація виявляє робочі місия з несприятливими умовами праці, на яких необхідно здійснити периочергові заходи по їх поліпшенню; робочі місия, виробництва, роботи, професії $і$ посади, працівникам яких пропонується встановити пільги і компенсачії за рахунок коштів підприємства; підтверджує право працівників на пільги і компенсаиії, передбачені законодавством.

Розглядається адаптація європейського підходу до організації моніторингу впливу виробничих факторів на безпеку та здоров'я людини, яка покладена в основу нових методичних рекомендацій по атестаиії робочих місиь за умовами праці. Пропонується перелік робіт з важкими, икідливими та небезпечними умовами праці на зернопереробних підприємствах. Вказуються помилки та недоліки при проведенні атестації.

Працівники харчової промисловості та переробки сільгосппродуктів отримують виробничі травми через такі фактори трудового процесу, як важкість та напруженість праці. Найчастіше причинами нещасних випадків (до 80\%) є причини організаційного характеру, у тому разі непроведення атестації робочих місиь за умовами праці (або порушення законодавства про атестацію робочих місць).

Ключові слова: атестація, робочі місия, умови прачі, виробниче середовище, небезпечні та шкідливі виробничі фактори, охорона прачі, важкість пращі, напруженість пращуі.

\section{ЛІТЕРАТУРА}

1. [Електронний ресурс] / Режим доступy: http://zakon2.rada.gov.ua/laws/show/178-18.

2. [Електронний ресурс] / Режим достулу: http://dsp.gov.ual

3. [Електронний ресурс] / Режим доступy: https://economics.unian.ua/agro/2375453-ukrajina-za-rik-zibrala-bilshe-61milyona-tonn-zerna.html

4. [Електронний ресурс] / Режим доступу: http://agravery.com/uk/posts/show/valovij-zbir-zernovih-v-ukraini-do-2020roku-moze-dosagti-100-mln-tonn

5. [Електронний ресурс] / Режим доступy: http://agravery.com/uk/posts/show/silskogospodarski-kompanii-demonstruutnajmensu-castku-problemnih-borgiv-nbu

6. [Електронний ресурс] / Режим достуny: http://nemyriv-rda.gov.ua/index.php/377-dotrymannia-vymoh-bezpeky-napidpryiemstvakh-zernozberihannia-i-pererobky-zerna

7. [Електронний ресурс] / Режим достуnу: http://www.dnop.gov.ua/index.php/uk/pres-sluzhba/vsi-novini/2254-1646

8. Про порядок проведення атестації робочих місиь за умовами праиі [Електронний ресурс] / Режим доступу: http://zakon.rada.gov.ua/laws/show/442-92-n.

9. Державні санітарні норми та правила "Гігієнічна класифікаиія праці за показниками шкідливості та небезпечності факторів виробничо го середовища, важкості та напруженості трудового процесу" // Офіційний вісник Украӥни 2014. - № 41. - C. 95-132.

10. Про затвердження Правил охорони прачі для праиівників, зайнятих на роботах зі зберігання та переробки зерна [Електронний ресурс] / Режим доступy: http://zakon.rada.gov.ua/laws/show/z1288-17.

11. Про затвердження Списків виробниџтв, робіт, професій, посад і показників, зайнятість в яких дає право на пенсію за віком на пільгових умовах [Електронний ресурс] / Pежим достуnу: http://zakon.rada.gov.ua/laws/show/461-2016$\% D 0 \% B F$.

12. Про затвердження Переліку виробництв, цехів, професій і посад із шкідливими умовами праці, робота в яких дає право на скорочену тривалість робочого тижня [Електронний ресурс] / Режим доступу: http://zakon.rada.gov.ua/laws/show/163-2001-\%D0\%BF14.

13. В.Б. Енгстрем. Розробка проекту методичних рекомендацій щодо проведення атестаиії робочих місиь за умовами праці / Енгстрем В.Б.// Інформаційний бюлетень з охорони праці. - №1(83) 2017. - C.32-43.

14. [Електронний ресурс] / Режим достуny: http://www.nibulon.com/data/investiciina-diyalnist/dlya-investoriv/promislovabezpeka-i-oxorona-zdorovya.html.

Надійила 21.08.2018. До друку 29.08.2018. Рецензія 29.08.2018 Адреса для переписки: вул. Канатна, 112, м. Одеса, 65039 